\title{
Migrantes africanos en Buenos Aires: Entre estigmatización y exotización ${ }^{1}$
}

\section{Régis Minvielle ${ }^{2}$}

ITM (Instituto Tecnológico Metropolitano), Medellín, Colombia ${ }^{3}$

$\mathrm{LPED}^{4}$

regisminvielle@itm.edu.co

Recibido: 13 de febrero de 2014

Aceptado: 17 de junio de 2014

Disponible en línea: 15 de marzo de 2015

\footnotetext{
Este artículo pretende exponer una parte de los resultados de un trabajo etnográfico que realicé para el programa de investigación Instancesreligieuses et d'origineconfessionnelle sur les routes de la migrationafricaine coordinada por Sophie Bava Institut Recherche Développement, Aix- Marseille Université - Francia) entre 2009 y 2012. Recibí una financiación del IRD, la cual me permitió viajar dos veces a Buenos Aires: en 2009 y en 2010.

2 Doctor en Sociologia de la Universidad Aix-Marseille

3 Docente

4 Investigador asociado del LPED (Laboratorio Población Medio ambiente y Desarrollo)
} 


\title{
Migrantes africanos en Buenos Aires: Entre estigmatización y exotización \\ Resumen
}

Desde la década de 1990, pero especialmente desde el año 2000, los inmigrantes procedentes en su mayoría de África occidental, tejen poco a poco los contornos de un dispositivo trasatlántico de migración Sur-Sur entre África y América latina. En Buenos Aires desarrollan una actividad de comercio callejero, iniciada principalmente por la comunidad senegalesa. Este artículo pretende sacar a la luz los estereotipos y las relaciones entre la sociedad argentina y los migrantes africanos con el fin de observar la recepción de una población desconocida en esa parte del continente. Para poder hacer esta investigación, me apoyé en el método etnográfico y el análisis de discursos. El carácter reciente de la migración africana hacia Argentina genera lugares comunes y prejuicios pero también una fascinación que toma raíz en el deseo de exotismo.

Palabras clave: migrantes; africanos; prejuicios; exotización; relaciones étnicas; Buenos Aires

\section{African Migrants in Buenos Aires: between Stigma and Exoticization}

\begin{abstract}
Since the 1990s decade, but especially since 2000, immigrants coming mostly from West Africa, have gradually weaved the contours of a transatlantic south-south migration device between Africa and Latin America. In Buenos Aires they trade on the streets. This activity was initiated mainly by the Senegalese community.This article aims to expose the stereotypes and the relationships between the Argentine society and the African migrants in order to observe the reception of an unknown population in that part of the continent. To do this research, the ethnographic method and discourse analysis were used. The recent nature of the African migration to Argentina generates clichés and prejudices but the desire for exoticism also gives rise to fascination.
\end{abstract}

Keywords: migrants; Africans; prejudices; exoticism; ethnic relations; Buenos Aires

\section{Migrantes africanos em Buenos Aires: Entre estigmatização e exotização}

\section{Resumo}

Desde a década de 1990, mas especialmente desde o ano 2000, os imigrantes procedentes na sua maioria de África ocidental, tecem pouco a pouco os contornos de um dispositivo transatlântico de migração Sul-Sul entre África e América latina. Em Buenos Aires desenvolvem uma atividade de comércio de rua, iniciada principalmente pela comunidade senegalesa. Este artigo pretende trazer à luz os estereótipos e os relacionamentos entre a sociedade argentina e os migrantes africanos a fim de observar a recepção de uma população desconhecida naquela parte do continente. Para poder fazer esta pesquisa, me vali do método etnográfico e a análise de discurso. A natureza recente da migração africana para Argentina gera lugares-comuns e preconceitos mas também uma fascinação que tem raiz no desejo de exotismo.

Palavras-chave: migrantes; africanos; preconceitos; exotização; relações étnicas; Buenos Aires 


\section{El contexto global de llegada}

Las nuevas migraciones africanas en América Latina hacen parte de un proceso de reconfiguración global del fenómeno migratorio. Los procedimientos de control cada vez más complejos en los países del Norte y la globalización de los países del Sur generan cierta diversificación en los destinos.

Europa, en relación con su pasado colonial, constituyó durante mucho tiempo un polo de atracción, especialmente después de la Segunda Guerra Mundial, cuando la necesidad de mano de obra era considerable para llevar a cabo las obras de reconstrucción. Pero con la progresiva desindustrialización y el ciclo de recesión económica, después de la edad de oro del capitalismo (que finaliza en 1973 con la crisis del petróleo), Europa pone en marcha, poco a poco, una política de contención de los flujos migratorios. El perfil del inmigrante-obrero deseado por la industria es remplazado por el perfil del inmigrante clandestino obligado a explorar los recursos precarios de la economía informal.

Hoy en día, en Europa la inmigración es considerada como inoportuna y el migrante está siendo criminalizado como lo demuestra Salvatore Palidda (Palidda, 1999). Esa inversión de las representaciones de los migrantes, de lo deseado a lo no deseado, se ilustra a través de los medios de comunicación que difunden de manera repetitiva, imágenes de lanchas con sobrecupo que navegan el estrecho de Gibraltar o cerca de la isla de Lampedusa. Esas percepciones negativas se traducen políticamente en la elaboración de un dispositivo de seguridad en las fronteras de la Unión Europea.

Al mismo tiempo, los Estados Unidos, en parte a causa del mito del self made man que proyecta hacia el mundo entero, seduce también a cada vez más africanos, tanto angloparlantes como francoparlantes. Esa atracción se manifiesta con un constante incremento del flujo migratorio, inclusive si acceder a una visa es una tarea muy complicada.

Es en ese contexto de redistribución del juego migratorio, con el cierre de Europa, la atracción de los Estados Unidos y ciertas políticas 
migratorias más favorables en América del Sur, que aparecen los primeros migrantes africanos, quienes a menudo, luego de haber fracasado en su intento de llegar a Europa, atraviesan el Atlántico para posar sus maletas en Brasil y Argentina. En la década de 1990 estos pioneros, principalmente originarios de Mali y que vivian en Libia, imaginan nuevos itinerarios para llegar a los Estados Unidos. Pero, antes de llegar al El Dorado estadounidense, necesitan primero reconstituir un capital económico. En esta época, Argentina disponía de una moneda fuerte, en paridad con el dólar, lo que constituye un factor muy atractivo para los migrantes que envian remesas a sus familias.

Si bien la migración de los pioneros malienses se queda en la sombra y no desemboca en una migración más importante, no sucede lo mismo con los senegaleses, quienes convertidos en modelo, favorecieron la llegada y la constitución de una red a partir de la década del 2000. El perfil de esos nuevos migrantes se distingue de los pioneros. No se aventuran como sus mayores pero se benefician, entre comillas, de un recorrido organizado y señalizado. Esta 'señalización' tiene un costo importante y se da en cada etapa del viaje, desde la organización en Senegal hasta el cruce de la frontera Brasil-Argentina.

Son jóvenes y para la gran mayoría es la primera salida de su país de origen. Provienen de una región productora de maní, con bajos niveles de escolaridad. En estas condiciones, el perfil del vendedor ambulante es el que se impone en el espacio público de Buenos Aires. Es el perfil más visible. Esa tendencia hacia la venta ambulante es la expresión de una profunda falta de competencias en un mercado laboral formal cada vez más competitivo y con facilidad de obtener ganancias rápidas. En Buenos Aires comercializan principalmente bisutería en el cosmopolita barrio Once, pero también en ferias y otros barrios de la capital.

La reciente emergencia de esa migración, su constante evolución, y la circulación entre los diferentes territorios del Cono sur hacen dificil su censo. El censo oficial de la población de Argentina en 2010 señala 2.738 africanos sin establecer distinciones entre las nacionalidades. 
Las asociaciones de migrantes hablan de 5.000 individuos, entre los cuales más de 3.000 serían senegaleses (Maffia, 2012). Es importante resaltar también que hasta el plan de regularización fomentado por la Dirección Nacional de Migración en enero del 2013, los senegaleses no contaban con entrada legal al país, dato que dificulta aún más la elaboración de un registro.

Insertándose en el tejido urbano, los migrantes africanos generan diversas reacciones e interrogan los estereotipos sobre África. En respuesta a estos lugares comunes, los africanos desarrollan a su vez, a lo largo de sus experiencias de la calle y de sus trayectorias, sus propias miradas. Con estos intercambios y miradas cruzadas tanto la cultura de los migrantes, como la de la sociedad receptora, se transforma. De esa manera, D. Schnapper subraya que toda cultura es el resultado de negociaciones constantes con el mundo exterior, negociaciones a través de las cuales se afirma, como un horizonte, una identidad que solamente se puede definir como una creación continua. (Schnapper, 1986,p. 151).

Por consiguiente en este caso la inscripción de los migrantes en el espacio público y su visibilidad en las calles contribuyen a redefinir un contexto identitario en un país en el que se afirmó la 'supremacía de la raza blanca y de la cultura europea' en la narrativa nacional (Frigiero, 2008). Si bien existen poblaciones de origen indigena y africano, estas fueron consideradas como extinguidas o exterminadas y en consecuencia, ausentes del imaginario colectivo. Dichos grupos fueron relegados a las zonas periféricas de las ciudades. Este proceso de negación e invizibilización es el resultado de una larga estrategia de Estado (Kleidermacher, 2011). Si la constitución nacional de 1853 incitaba 'a todos los hombres del mundo' a poblar el desierto argentino, el contexto ideológico del evolucionalismo social que postulaba la superioridad de las sociedades europeas, induce un proceso de selección de los inmigrantes.

En este proceso los más deseables debían ser originarios preferiblemente de Euopa, las primeras sociedades que realizaron su revolución industrial. El objetivo del poder político era reemplazar las poblaciones 
originarias, consideradas como 'bárbaras', por poblaciones percibidas como estandartes de modernidad (Alberdi, 1852). Entre 1881 y 1914 se registraron cerca de dos millones de italianos, 1'400.000 espanoles y 170.000 franceses que llegan a Argentina, los cuales debian cumplir con los parámetros de construcción de la nacionalidad basados en la asimilación a través del objetivo de fusionar "en una sola todas las razas que representan los individuos que vienen a sentarse al hogar del pueblo argentino". (Devoto, 2009).

Este discurso asimilacionista -válido hasta finales de los años 1980- deja lugar a una narrativa multicultural que resulta de una necesidad de emitir señales de buena gestión hacia sus minorías en un contexto de hegemonía neoliberal. Esa perspectiva, como lo muestran Briones, Cañuqueo y Kropffy Leuman:

[...] postula la interculturalidad como valor, recurso, y dato diagnóstico clave para la fijación de políticas sociales en nuestro país y en el mundo, los procesos de flexibilización de capital que amplifican y concentran nuevas riquezas también multiplican nuevas pobrezas. (2007, p. 267)

Ese proceso de construcción nacional desde la negación de los negros y los indígenas hacia un multiculturalismo reciente y neoliberal, incide sobre la construcción de los prejuicios hacia los migrantes africanos.

\section{Crónica de lugares comunes sobre los africanos: el ejemplo de una publicidad}

La instalación del recién llegado y con mayor motivo cuando proviene de un lugar muy lejano, hace surgir un desencadenamiento de sentimientos y discursos. Poco acostumbrada a convivir con esa alteridad, la población autóctona expresa a veces un miedo, una animosidad o al contrario una cierta atracción. Comparado con otros extranjeros, se atribuye al recién llegado tal defecto y tal virtud. En un impulso esencialista, está caracterizado según un solo origen y encarna el Otro que 
en el caso del africano, está ausente de la sociedad argentina desde la llegada de los Caboverdianos ${ }^{5}$. El origen del extranjero evoca directamente un 'allá' que sin embargo no es totalmente desconocido. Puede representar un lugar donde se soñaría ir o al contrario, que inspira desconfianza. En otros términos, ese 'allá' genera un imaginario cargado en las maletas del migrante. ¿Es este un 'mensajero de sentido'? (Nal, 2012). ¿La recepción del otro no es finalmente el producto de ese conjunto de percepciones? Interrogarse sobre esto implica interrogarse sobre sus condiciones de producción.

En Argentina, como en las otras sociedades occidentales, medios y periodistas desempeñan un gran papel en el proceso de elaboración de una imagen, proponiendo una lectura selectiva según la cual la actualidad africana abarca el mismo modus operandi: subrayando un África indivisible y asolada por la hambruna, las epidemias, los desplazados y las guerras étnicas. Los medios suministran la idea de un continente a la deriva. Al lado de esas imágenes de desolación, otros documentales despliegan el reino animal. Desde el corazón de la gran selva del Congo hasta el Sahara, desde el techo de África en Etiopia hasta el extremo sur del cabo de Buena Esperanza, esas imágenes describen un África salvaje, guardiana de autenticidad y última muralla contra la modernidad.

Para ilustrar estos lugares comunes voy a apoyarme en una publicidad que adquirió cierta notoriedad en la sociedad argentina. La fabricación de imágenes constituye un material pertinente en la medida en que permite dar cuenta de los significantes sobre África. Además del análisis de la publicidad, daré ejemplos concretos de los estereotipos que los africanos y en especial los vendedores ambulantes, se ven obligados a enfrentar.

La publicidad de un proveedor de internet despliega una colección de estereotipos dirigidos a África y a los africanos. El anuncio publicitario cuenta la historia de un inmigrante africano en Argentina que por internet, ve los partidos de fútbol de su país de origen. Sus

\footnotetext{
5 Ver los trabajos de M. Maffia o de L. Contarino Sparta, quienes participaron en el análisis de la migración caboverdiana en Argentina que sucedió entre finales del siglo XIX y 1960.
} 
celebraciones de gol a altas horas de la noche generan reacciones de indignación en sus vecinos argentinos. Por temor de represalias y para evitar que esa situación se vuelva a producir, decide comprar -on linea su jugador de fútbol favorito, llamado Mukenio, y lo transfiere del club de la ciudad de Korogwe ${ }^{6}$ a un club argentino. Además del mensaje publicitario, que consiste en transmitir el acceso al exotismo gracias a internet, aparece una serie extraordinaria de lugares comunes y prejuicios en solo 58 segundos $^{7}$.

El video puede dividirse en dos secuencias:

- En África: La primera escena muestra un retrato dibujado del jugador de fútbol. Primero que todo, impacta la imagen caricatural del africano que hace recordar la imagen de las campañas publicitarias de la marca francesa de chocolate en polvo Banania ${ }^{8}$. Según el mismo modo, sobre un fondo amarillo, la pintura deja aparecer rasgos exagerados: labios gruesos, pómulos redondeados, nariz sobredimensionada.

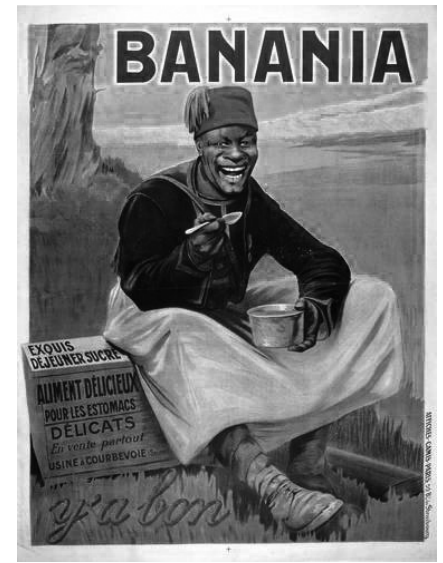

Figura 1. Primer afiche publicitario de la marca Banania (1915). Archives des Hauts de Seine.

6 Ciudad de la región de Tanga en Tanzania.

7 La publicidad se puede ver en el siguiente enlace: http://www.youtube.com/watch?v=tHhrXe5KUlE

8 La marca francesa, creada en 1914, se volvió famosa a través sus campañas publicitarias a lo largo de todo el siglo XX. Pierre Lardet, fundador de la marca, aprovecha la popularidad de las tropas coloniales para lanzar su producto. Con el slogan "y a bon Banania", en un francés incorrecto y significando, "esta bueno banania", la marca contribuye a difundir estereotipos de inferioridad vinculados con la historia colonial. 


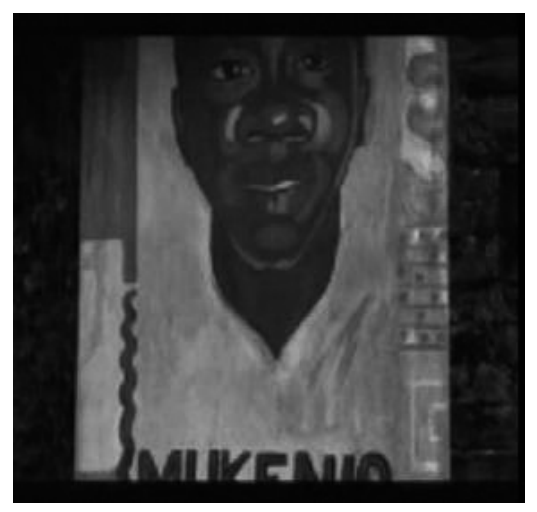

Figura 2. Captura de una imagen de la publicidad, 2003. http://www.youtube.com/ watch?v=tHhrXe5KU1E

Esta primera escena acompasada por los sonidos del balafón, sume de una vez al telespectador en un 'ambiente africano'; sin embargo el director prefiere aclarar la ubicación geográfica a través de la inscripción Korogwe, África a pie de pantalla. Luego, el televidente puede seguir un partido de fútbol que se desempeña bajo el calor tropical simbolizado por las palmas y por las vestimentas. Todas las imágenes remiten a los significantes de un África subdesarrollada y deprimida a través de la vetustez de sus infraestructuras e instalaciones. Las carreteras no tienen asfalto, el habitáculo del relatador es insalubre. Rodeado por unas gallinas, está sentado en una silla exageradamente usada y declama palabras de kiswahili ${ }^{9}$ en un micrófono completamente obsoleto. Su vestimenta es totalmente ridícula, lleva un traje de chaqueta pero con una pantaloneta de estilo hawaiana y gafas oscuras que le tapan la mitad de su cara. Esa imagen extravagante del personaje se destina a mostrar una falta de profesionalismo.

En un país como Argentina, donde el fútbol está escrutado, analizado y sujeto a todas las discusiones, presentar un periodista deportivo bajo un modo burlesco y extravagante expresa una idea de condescendencia. En el mismo sentido, las camisetas de los jugadores son de una época pasada. La cancha de fútbol se parece más a un terreno baldío

\footnotetext{
9 Idioma oficial de Tanzania
} 
que a un estadio deportivo. Una escena muestra también a varios adolescentes con el torso desnudo, montados en árboles para mirar el partido. Esa imagen expresa cierto primitivismo que consiste en reducir al hombre a un estado de naturaleza.

Al final de la primera secuencia aparece un militar en primer plano que parece dispuesto a usar su metralleta para calmar una multitud en delirio. Esa imagen remite a las características de una dictadura o de una república bananera.

La segunda secuencia, que se desarrolla en Argentina, muestra un contraste notable con la primera. El trato de la escala de los lugares es desigual. En la primera escena, la inscripción en la pantalla de los términos Korogwe Africa no indica el país en el cual sucede la escena. Los autores de la publicidad quieren subrayar la palabra África ocultando la realidad múltiple y compleja del continente. En ese sentido, es muy común ver a los senegaleses en las calles de Buenos Aires explicando sus orígenes a los paseantes: "No, África, no es un país, es un continente. Yo soy de Senegal".

En contraste, el termino Núñez, nombre de un barrio de Buenos Aires, fijado en la pantalla, da mucha más precisión del lugar de la escena. El publicista construye niveles de información distintos para llevar así a la pantalla un África esencializada en oposición a una Argentina diversa.

Según esa misma lógica de oposición, el televidente puede observar sucesivamente en esa secuencia un edificio de muchos pisos, un apartamento cómodo, autobuses resplandecientes que circulan en carreteras asfaltadas, una sala de aeropuerto e instalaciones deportivas recientes. Todas esas infraestructuras conforman los atributos de la modernidad, que según las imágenes precedentes, es desconocida para los africanos. El paroxismo de la interiorización culmina cuando se ve al inmigrante africano esperando a su compatriota futbolista con un cartel, que además de su nombre tiene su retrato, lo que deja suponer que el jugador no sabe leer. 
Después de la figura del exuberante comentarista deportivo que divierte al público en la secuencia africana inicial, aparece luego la figura del ignorante. Para dar forma al significante del africano 'simple', el publicista usa el mismo procedimiento de la marca Banania, haciendo que el protagonista principal se exprese en un lenguaje primario. El eslogan ' $Y$ a bon Banania' se inspira del 'petit nègre'. Originariamente, esa expresión designa la enseñanza del idioma francés simplificado y dirigido a los pueblos colonizados.

Poco a poco, la expresión petit nègre se afirmó en el léxico lingüístico para calificar los errores gramaticales y de sintaxis. El término contiene una carga muy estigmatizante, en el sentido que se hace una correlación entre la ignorancia y un grupo humano específico. En Latinoamérica, el uso desviado del idioma puede tener las mismas funciones de inferiorización. En la publicidad, el inmigrante africano acusado por sus vecinos de escándalo nocturno, se disculpa en esos términos: "Disculparme, no lo voy a hacer más". Esa manera de hablar remite también a la figura del niño que está en una etapa de socialización con el lenguaje. Muchas veces los niños suscitan la hilaridad de los adultos cuando cometen errores. Presentar al africano bajo un aspecto infantil lo pone de entrada en una relación desigual con sus interlocutores argentinos.

Por otra parte, la escena en la que podemos ver al inmigrante comprando a un deportista africano a través de internet por un monto irrisorio de 450 dólares, demuestra el valor insignificante atribuido a los jugadores africanos. La lógica de mercantilización del ser humano, que consiste en desplazarlo de un continente a otro con un simple click, ¿no es finalmente la expresión inconsciente de una versión moderna de la trata de esclavos?

Al final, la publicidad concluye con un pequeño baile del africano, una serie de contoneos. El objetivo es terminar la película con una nota positiva que hace recordar que los africanos son ante todo seres felices y simpáticos. Pero la imagen evoca también a un payaso que tiene que divertir a los otros. 
En conclusión esta publicidad abarca muchos estereotipos: el africano es representado simultáneamente como ingenuo, risueño, ignorante, salvaje o subdesarrollado, es decir categorias todas inferiorizantes.

En sus vidas cotidianas, los migrantes africanos se enfrentan a este imaginario. Maxime es camerunés y tiene un restaurante en el barrio Villa Crespo. La poca oferta de gastronomía proveniente del continente africano y la calidad de su carta le hicieron adquirir cierta notoriedad en Buenos Aires. Ha aparecido en varios artículos de prensa y participado en programas de televisión especializados en cocina. En varias ocasiones, Maxime es invitado a conformarse con el papel del que entretiene, teniéndose que someter a mostrar algunos pasos de baile en una emisión de gastronomía. El presentador de "Cocineros Argentinos", transmitido en la televisión pública, comenta su demonstración con observaciones esencialistas como "los africanos nacen bailarines", o "hace parte de su cultura", por ejemplo. Esas representaciones naturalistas pueden también enunciarse según la modalidad del tribalismo. El presentador pregunta primero a Maxime a qué tribu pertenece y luego, como introducción al programa, muestra un pequeño reportaje sobre Camerún. En él dice:

La colonización francesa influenció las costumbres de Camerún mezcladas con la tradición ancestral de sus tribus nativas. Los franceses introdujeron el pan, pero la cocina estuvo influenciada por otras tribus quienes cruzaron el país entero hasta el mar.(Cocineros Argentinos, TV Pública Argentina, 4 de mayo de 2011)

El testimonio de Bakari, contado también por otros migrantes africanos en Argentina, corrobora esa visión del otro atrasado y salvaje:

Nos preguntan a menudo si en África dormimos en los árboles. Hay cosas con las cuales no aguanto más. Miraba la televisión por ejemplo. Una vez, vi un documental donde hacían una comparación entre los negros y los animales. Era un documental sobre los negros en África y habían dividido la pantalla en dos. Por un lado había las actividades de los africanos y por otro lado, había actividades de 
unos micos, es muy grave eso. Otro dia, hablaban de los bailes africanos. Hacían una comparación entre un baile africano y un cierto tipo de salto de pájaro. También habían dividido la pantalla en dos. Es increíble.(Bakari, entrevista, 31 de agosto de 2010).

\section{Los vendedores ambulantes en primera linea}

Sin duda, los más expuestos a ese imaginario despectivo son los vendedores de la calle. Su inscripción en el espacio público los pone en contacto con una multitud de personas. Esa visibilidad, fortalecida con la brillantez de sus mercancías, reconfigura el paisaje urbano porteño. Los migrantes africanos generan reacciones diferentes a las de otras poblaciones latinoamericanas que ocupan el mismo espacio. Mientras los migrantes peruanos o bolivianos captan los miedos y las diferentes formas de rechazo y de exclusión basadas en una retórica de la invasión, los africanos inspiran más bien el asombro y la curiosidad. Si alguna gente se limita a echar una mirada estupefacta, otros los interpelan para preguntarlos las razones de su presencia. El Hadj, joven senegalés de 25 años, contesta siempre con los mismos argumentos:

Nosotros venimos para trabajar y ayudar a nuestra familia. En Senegal no hay dinero, no hay trabajo, es por eso que salimos. (E1 Hadj, entrevista, 20 de septiembre de 2009)

Esa forma de legitimar la emigración expresa una postura que coincide con un discurso dominante. Los medios, los políticos, pero también las ONG, miran las migraciones bajo la problemática del desarrollo económico y sus variables. En este marco de pensamiento exclusivo, es la urgencia que determina los comportamientos de unos migrantes dispuestos a usar todos los medios para huir de una realidad opresiva. Tanto la pluma de los periodistas argentinos, como la de sus colegas europeos o norteamericanos, sobreestima y exalta las cruzadas clandestinas a bordo de los buques de carga. Estos relatos generan en los lectores sentimientos de compasión. Para los vendedores de la calle, mantener ese mito corresponde a una estrategia 
comercial. Para aumentar las ventas, hay que mostrarse como una persona de muy pocos recursos y despertar sentimientos paternalistas y caritativos:

Yo vine en avión. Pero como siempre me hacen la pregunta del barco, o sea si tomé un barco para llegar acá a Argentina, entonces les contesto que sí, que me subí en un barco para venir acá porque me iban a matar, por la guerra. Yo sé que les da pena, y después hay unos que me compran. (El Hadj, entrevista, 20 de septiembre de 2009)

Algunos senegaleses integran esas representaciones en sus técnicas de venta. El look y la manera de vestirse constituyen modalidades de distinción que se pueden movilizar para atraer a los clientes o para afirmar una identidad. Permiten enviar mensajes a la población. Los usos del aspecto son múltiples: se puede tratar de llamar la atención a través de una vestimenta vistosa, destacada o al contrario, hacerse discreto para mantener un perfil bajo.

En un deseo de encarnar una juventud globalizada, algunos vendedores buscan imitar a sus modelos, los cuales pueden ser futbolistas, raperos, artistas o grandes negociantes. Bamba por ejemplo,adopta la moda reggae llevando largas trenzas, pantalones amplios y camisas con los colores de Jamaica. Muchos son los que llevan bluyín, camisetas de fútbol de sus clubes europeos favoritos como Manchester United, Arsenal, el Barça o el Real Madrid, y tenis de la famosa marca Nike. Otros se apropian el look del rapero que se caracteriza por sus pantalones extra-amplios, gorras y a veces gruesas cadenas. Está también el seductor que se preocupa por la coherencia y la armonía de lo que lleva puesto. Cambia de vestimenta con frecuencia y puede ser a veces muy elegante y otras veces más casual. Usa su creatividad para sentirse único, seducir mujeres y ponerse a distancia de su grupo de origen.

Esas actitudes diversas y demostrativas en las cuales las marcas tienen un efecto de ostentación, van en contra corriente con los lugares comunes que consideran que los africanos son todos idénticos: desnudos y necesitados. Lejos de plegarse a los prejuicios, al contrario de los que lo transforman en argumento de venta, esos jóvenes inmigrantes 
expresan un deseo de pertenecer a un mundo globalizado y de parecerse a muchos jóvenes del mundo, incluidos los latinoamericanos.

En oposición a estos modelos de extraversión del individuo, otros abandonan voluntariamente la ropa de marca para vestirse de manera discreta y neutra. Bluyín, camiseta, tenis sobrios o sandalias, constituyen atributos del vendedor que busca esconder cualquier signo de riqueza que podria despertar sospechas de parte de sus clientes. Los vendedores intentan conformarse con la imagen del pobre, estrategia que permite, según ellos, facilitar las ventas: se trata de no aparecer más rico que el comprador potencial sino de ponerse decididamente en una postura de inferioridad en relación con su interlocutor y dejarlo creer que realiza un acto de caridad cuando compra una joya. La idea es mantener posiciones en la estructura social con el fin de evitar un replanteamiento de las representaciones sobre la actividad de la venta ambulante.

Pero no siempre se expresa compasión en la calle. Este exotismo importado en las calles de Buenos Aires provoca también burlas diversas: a veces sobre su manera de hablar, otras veces sobre el color 'muy oscuro' de su piel o sobre su apariencia en general. Algunos porteños no vacilan en tomarles fotografias, o hacerse fotografiar con ellos. Otros, más temerarios, les tocan el cráneo con el pretexto de que trae buena suerte. Lo que significa diversión para unos, provoca la indignación de los africanos quienes, en reacción a esa estigmatización, afirman entonces sus prejuicios frente a los argentinos. Ese punto de vista contrasta con la conformidad del estereotipo de sufrimiento generalizado en África.

Una vez tomé un taxi. El conductor dijo que era gorda porque me engordé acá en Argentina porque en África se muere de hambre. Era un cabrón. Le contesté que ya era gorda en África y que en África nadie buscaba comida en la basura como acá. (Binta, entrevista, 7 de julio de 2010)

Acá para la gente, los negros son como animales, piensan que dormimos con los leones y que no tenemos nada, piensan que somos 
pobres y que nos vamos de la guerra. Son unos tontos. (El Hadj, entrevista, 14 de septiembre de 2009)

No saben que venimos acá para trabajar. Los argentinos, nos tienen miedo. Podrían robarnos pero piensan que no tenemos dinero. Los conductores de buses no se detienen cuando nos ven. A veces, la gente me pregunta si duermo en los árboles. Ellos no saben nada, para ellos, somos todos iguales, pobres e imbéciles pero ellos son ignorantes, nunca viajaron, nunca salieron de sus casas. (Amadou, entrevista, 21 de octubre de 2009)

En estos relatos, podemos darnos cuenta de que el estigma no es parte de una identidad pasivamente aceptada. Las descalificaciones provocan luchas simbólicas, conflictos de definiciones y de redefiniciones. Esa lógica de resistencia busca invertir el estigma en un elemento positivo de identidad. Mientras, por ejemplo, los afrodescendientes contestan a las discriminaciones que los afectan, haciendo de su negritud una cualidad positiva, los senegaleses subrayan más bien sus condiciones de migrante. Consideran la migración como un experiencia positiva y como un proceso de socialización que les permite adquirir nuevos conocimientos (lingüisticos, culturales). La identidad de migrante se construye en parte por oposición a los locales, los que son ignorantes porque no viajan.

Alassane se diferencia de los migrantes que acabo de citar, guardando más reserva en su discurso. Si bien reconoce la preponderancia de los prejuicios frente a los africanos, no los considera como algo irreversible. Al contrario de la mayoría de sus compatriotas, Alassane no llegó a Argentina en los últimos años sino en 1996 y conoce una trayectoria social ascendente. Labora en la industria automóvil con un empleo fijo y ha podido comprar una casa en el Gran Buenos Aires en 2007. Su éxito social y su vida laboral lejos de las calles, tienden a reducir las divisiones y redefinen las miradas.

Cuando llegué acá, al principio era muy dificil, no había negros. Cuando me veían arreglar un auto, nadie podía creer que un africano podía hacer eso. Pensaban que no había autos en África. Lo único 
que los argentinos sabían de África, era el partido de fútbol del mundial entre Camerún y Argentina. Pero poco a poco, se puede ganar la confianza. Se dieron cuenta que hacía bien mi trabajo, que sabía de mecánica. Si uno es serio no hay problemas, yo tengo muchos amigos argentinos. (Alassane, entrevista, 16 de julio de 2010)

En conclusión, en Argentina la gran mayoría de migrantes africanos está expuesta a una serie de prejuicios y lugares comunes que son el producto de una herencia de la esclavitud y de las imágenes postcoloniales que se enfocan en la problemática del subdesarrollo. En esa construcción social de la mirada sobre el otro que hace de la diferencia una hipérbole, otros tipos de actitudes se desarrollan.

\section{Las relaciones intimas: entre deseos y conflictos}

Ese interés por el otro, por el que viene de afuera y que trae con él sus diferencias, puede revelar también un objetivo más allá de la simple búsqueda de satisfacer un deseo de curiosidad. De esas interacciones fortuitas, pueden surgir relaciones más íntimas que se conjugan principalmente con el exotismo. Para los africanos se trata de convocar elementos de personalidad que hacen referencia a lo extraño como objeto de deseo.

Mientras la palabra estigma se usa para "designar un atributo que arroja un descrédito profundo" Goffman, 1963, p.13), la exotización puede ser entendida como un conjunto de procesos destinados a definir la diferencia, no a partir de una carga negativa, sino en relación con la atracción. La exotización se basa en un extraño idealizado, en oposición a una estigmatización de la diferencia que puede ser construida por el color de la piel, una discapacidad o una orientación sexual. Sin embargo, estas dos visiones del otro comparten la misma tendencia a producir estereotipos. En el caso de la exotización, se trata de caricaturizar actitudes y homogeneizar identidades bajo el prisma de explicaciones culturalistas y/o naturalistas. 
El interés principal del africano, que se ubica en la posición del seductor, es emitir una imagen esperada en la cual su individualidad está negada para poner en el centro la afiliación a un grupo. Como lo examina Goffman:

La identidad social y personal forma parte, ante todo, de las expectativas y definiciones que tienen otras personas respecto del individuo cuya identidad se cuestiona. En el caso de la identidad personal, esas expectativas y definiciones pueden surgir aún antes de que el individuo nazca, y continuar después de su muerte, es decir que existen, entonces, en momentos en que el individuo carece totalmente de sensaciones y, por supuesto, de sensaciones de identidad. (Goffman, 1963, p. 126)

Es entonces primero en la mirada de los otros, y más aún en la mirada de la mayoria, que se crea "una diferencia sincrética, amalgama de rasgos físicos psíquicos, culturales y sociales" (Poiret, 2011, p.114). Para el seductor, como también en el caso de otros roles sociales, se trata de aprender a vivir y a veces interiorizar estereotipos que expresan "el repertorio limitativo de características del grupo" (Guillaumin, 2002/1972). En esa modalidad que está relacionada con una historia colonial, el negro es definido como cercano a la naturaleza y se caracteriza por una bestialidad que se puede expresar negativa o positivamente. Es sobre ese imaginario positivo que se asimila el cuerpo del negro a una naturalidad salvaje en la que el deseo femenino toma raíz. En ese esquema de referentes y de categorización, el africano tiene que ser el que trae 'colores y sabores nuevos', el que tiene 'el ritmo en la piel', el que es 'sensual', siempre 'alegre, espontáneo y resistente' porque está dotado de una 'fuerza física superior'10.

Estos estereotipos están también relacionados con la negritud latinoamericana. Como los africanos, los migrantes brasileños son muy poco numerosos, contrario a los bolivianos o paraguayos. En 1991, representa solamente el cuatro por ciento de la población inmigrante y limitrofe (Frigerio, 2005). La poca relevancia de esos flujos, los cuales se componen principalmente de la clase media poseedora de un capital

\footnotetext{
${ }_{10}$ Términos usados por argentinas que tienen o tuvieron una relación con un africano.
} 
económico y cultural, y la intensificación de viajes turísticos entre los dos países, favorecieron la construcción de un imaginario positivo.

La aparición de boliches brasileños en Buenos Aires, donde se puede escuchar solamente música brasileña, es la importación de un modelo cultural del nordeste brasileño y más en particular de la ciudad de Bahía. Esa preeminencia de Bahía, famosa por su carnaval africano en la cultura brasileña de Buenos Aires, se expresa también en otros ámbitos como el baile afro-brasileño o la capoeira. Por otra parte, el crecimiento constante de turistas argentinos hacia Bahía contribuyó a difundir también la cultura bahiana en Buenos Aires.

En un país que se piensa blanco y europeo, la conexión, (Amselle, 2001) con Bahía saca a la luz esos deseos del allá, del extraño y estas inclinaciones por la diferencia simbolizada por las culturas negras. Para satisfacer estos deseos, algunas porteñas van a estos lugares de fiesta primero para bailar samba con brasileños negros y luego eventualmente, para dedicarse a unas prácticas más íntimas.

Esa contextualización de las relaciones raciales de género permite entender cómo se establecen las formas de intimidades entre mujeres argentinas y africanos. Tanto para los brasileños como para los africanos, las atracciones que ocasionan responden a lógicas similares de exotización. En respuesta a esa atracción y a esos lazos de intimidad, los senegaleses producen sus propios estereotipos. Cuando interrogamos a los senegaleses sobre las argentinas, la mayoría las presenta como chicas fáciles con una moralidad dudosa. El Hadj afirma:

Las mujeres aquí no tienen ninguna regla, ¿viste? Algunas vienen a verme con bebés y no están interesadas en comprarme algo pero quieren hablar conmigo. Yo les pregunto: ¿Estás casada? -No, estoy separada. En Senegal no es posible eso. Acá, las chicas buscan nuestra sangre, nuestra piel... En Senegal las chicas no se visten sexy como aquí. (E1 Hadj, entrevista, 14 de septiembre de 2009)

En los discursos de los senegaleses, la mujer argentina es sistemáticamente presentada como una amenaza de la que hay que protegerse. 
Esa postura tiene que ser contextualizada con la doctrina religiosa del islam sufi que atribuye una posición inferior a la mujer en la jerarquía social. En la sociedad wolof ${ }^{11}$, se atribuyen funciones y cualidades distintas a los linajes uterinos y agnaticios. Como lo subraya Diop, en las representaciones sociales, la valentía, los nervios y los huesos son transmitidos por el linaje agnaticio, mientras que la sangre, el carácter y la inteligencia son transmitidos por la madre.

El linaje uterino crea un parentesco más cercano que el linaje agnaticio [...] Los Wolof creen que la suerte del niño depende de la conducta de su madre. Tienen esa noción de ndey-ju-liggey "madre que ha trabajado muy bien", lo que significa en realidad, esposa modelo. Una mujer cuya conducta es irreprochable frente a su esposo, tendrá niños exitosos. (Diop, 1985, pp. 19-23, traducción del francés: Régis Minvielle)

En esa distribución de los roles, las mujeres son las garantes de la transmisión de los valores y las tradiciones y asumen la responsabilidad de la socialización de los niños con las normas culturales. La mujer está entonces principalmente percibida a través de su figura materna, la cual está sacralizada y es intocable. (Pezeril, 2007). Por consiguiente, este estatuto la ubica en situación de sumisión frente a su esposo en la medida en que la educación de los niños en coherencia con el modelo social dominante depende de sus comportamientos. Existe una imbricación entre el rol de esposa y el rol de madre, que invita a las mujeres a comportarse como esposas correctas con el fin de no poner en peligro el equilibrio familiar.

Aunque se debe matizar esa sumisión por ejemplo, con el derecho al divorcio, la dominación masculina no es solamente una realidad, sino también una pauta que estructura las representaciones en las relaciones de género. Por otra parte, estas representaciones están reforzadas por la ortodoxia religiosa. En el islam, como en la mayoría de las religiones reveladas, la mujer encarna el pecado y la tentación que aleja al seguidor de Dios. Influenciados por ese imaginario, el discurso de los jóvenes senegaleses frente a las mujeres argentinas está

\footnotetext{
${ }^{11}$ Los Wolof constituyen la etnia mayoritaria del Senegal. Están también presentes en Gambia, Mauritania o Mali. Hablan el idioma wolof y son musulmanes.
} 
cubierto de desprecio. Modou, por ejemplo, condena ardientemente sus costumbres:

Se acuestan con cualquiera. No se les puede dar confianza. Yo, con las chicas así, me divierto, no más, porque no es serio, eso. Con las argentinas es muy fácil. Nos invitan a sus casas. En Senegal, no es posible eso. (Modou, entrevista, 12 de Agosto de 2009)

Para justificar sus prácticas sexuales, que se oponen a la ética religiosa y transgreden las normas divinas, los senegaleses invocan entonces la victimización:

Son ellas que vienen a buscarnos. Quieren nuestra piel negra. Nos dicen que los argentinos no las satisfacen. (Alou, entrevista, 22 de septiembre de 2009)

Hay que subrayar también que ese tipo de prácticas, consideradas como transgresivas, no se encuentran solamente en los lugares de inmigración. La sociedad senegalesa también atraviesa cambios sociales importantes. Bajo el impulso de una creciente urbanización y de una individualización de las relaciones sociales, se dan nuevos tipos de uniones (unión libre, matrimonios tardíos, celibato) y nuevas conductas sexuales (relaciones sexuales preconyugales). A pesar de las resistencias a estos cambios, que se expresan por ejemplo con la prohibición de tener relaciones sexuales por fuera del matrimonio, El Hadj afirma sin embargo que esas reglas tácitas, a pesar del control social que se aplica más contundentemente sobre las mujeres, pueden ser transgredidas. Luego de una conversación en la cual evocaba su vida sexual desenfrenada en Argentina, simbolizada por una acumulación y a veces por una simultaneidad de relaciones intimas, El Hadj subraya también:

En Senegal hacía lo mismo. Tenía cuatro novias al mismo tiempo. Les decía que vinieran al escondido después de que mi padre salía de la casa y entonces hacíamos el amor. (El Hadj entrevista, 30 de septiembre de 2009) 
Pero más allá de simples aventuras sexuales sin futuro, también pueden instaurarse unas relaciones de género más durables. Mientras que los discursos de circunstancia transforman a las mujeres en objeto de deseo, las prácticas revelan otras realidades que desbordan el marco restringido de la sexualidad. Sin hablar de matrimonios mixtos y descendencias inducidas, de esas relaciones nacen afinidades y proyectos comunes de vida, relaciones que sin embargo, son señaladas por los migrantes africanos como libertinas o fútiles.

Sin embargo, los senegaleses, atrapados entre una ética religiosa y una atracción hacia las porteñas, temen comprometerse.

Yo tengo un amigo, su novia quiere casarse con él y que se vayan a vivir juntos en la casa de ella. Yo le recomendé que no lo hiciera. En Senegal, nunca nos vamos a vivir en la familia de la esposa. Acá, la única cosa que les interesa con nosotros es el sexo, siempre quieren más. Yo no me voy a casar acá, pero tengo sexo de vez en cuando. (Modou, entrevista, 26 de septiembre de 2009)

Aquí se expresa la inquietud de que sus novias pongan en duda la dominación masculina y reivindiquen relaciones más igualitarias. Amadou confirma esa amenaza. Él acumuló varias relaciones largas (tres relaciones estables en un periodo de tres años). Sus experiencias sacan a la luz las tensiones relacionadas con el estatuto de la mujer dentro de la jerarquía de las relaciones de género. Apoyándose en su origen africano, Amadou busca legitimar una superioridad masculina:

¿Viste acá las chicas? Ellas mandan. Los blancos no saben mandar a las mujeres. En África no es así. Es el hombre que dice a la mujer lo que tiene que hacer. Por ejemplo mi ex novia, cuando venía a mi casa, no preparaba la comida. Se acostaba en la cama y miraba televisión todo el tiempo. Su casa era sucia, no hacía el aseo. Cada vez que peleamos por eso, no quería hacer nada. Entonces, no aguanté más y dije basta. Con Camila, la segunda novia, al principio, se preocupaba por mí, me preparaba milanesa, me cuidaba, era bien. Pero luego se cansó. Pero esto no es serio, ¿viste? Una mujer no se puede 
cansar de eso. Además, quería salir de noche con sus amigas. No es serio eso. (Amadou, entrevista, 26 de septiembre de 2009).

Sin embargo, sería reduccionista considerar esos puntos de fricción y las incomprensiones en las parejas mixtas a partir de la única variable de género y las representaciones que le pertenecen. Mientras la experiencia de Aziz confirma ese sentimiento de indignación ligado a una pérdida de virilidad, la actividad económica también es otro foco de tensión, como en el caso de Amadou. La amplitud del tiempo de trabajo responde a una lógica de rentabilidad con el fin de poder mandar la mayor cantidad de remesas posible a sus familias. Estas obligaciones implican una dedicación total a la vida laboral y pueden constituir un obstáculo en la vida de pareja. Por otra parte, el temor de ver un capital económico agrietarse y perder su control bajo el efecto de los gastos generados por una nueva economía doméstica, lleva a menudo a los senegaleses a declinar propuestas de unión libre. Ese temor por el compromiso es interpretado por las novias como un déficit de implicación en la relación y genera conflictos dentro de la pareja. Muchas veces estos conflictos desencadenan en rupturas, como es el caso de Aziz y Cristina.

Era muy inda y nos llevábamos muy bien. Ella quería hacer su vida conmigo, instalarse en un departamento, tener hijos. Pero yo no quería. No tengo suficiente dinero para eso y tengo que mandar dinero a Senegal. Tengo que pensar en mí en prioridad [en realidad en la familia], y no en ella. ¿Viste? acá tuve que abandonar mis costumbres; me pagaba el restaurante, el cine. En Senegal es el hombre el que hace todo eso pero yo acepté. ¿Viste? a veces el domingo, quería ir al teatro, pero yo trabajo. Yo tengo que trabajar. No puedo parar de trabajar, para poder mandar dinero a Senegal. (Aziz, entrevista, 3 de octubre de 2009).

De manera menos matizada, Modou acusa a las mujeres de no entender esa repartición desigual entre tiempo de trabajo y tiempo para la pareja. Sus declaraciones subrayan también el apego a la vida comunitaria y sus lazos de solidaridad, que una vida en pareja podría distender. 
Además, acá, después no te dejan trabajar. Quieren siempre estar con vos. Luego si vas a vivir con ella, no puedes ver más a tus amigos. Acá estamos lejos de casa, es difícil, necesitamos a nuestros hermanos aquí. (Modou, entrevista, 8 de octubre de 2010)

En conclusión, la observación de relaciones íntimas permite aclarar las tensiones en juego dentro de las recomposiciones identitarias y los procesos de negociación entre los migrantes africanos y la sociedad argentina. No es fácil para el recién llegado conciliar obligaciones familiares, la vida comunitaria, las normas sociales y religiosas de origen con esas relaciones de género. Los migrantes africanos se ven entonces obligados a navegar dentro de las paradojas de la alteridad (Sayad, 2006):

Para el sociólogo, esta paradoja sustenta toda inmigración que no puede deshacerse de la otra cara de su realidad, es decir una emigración que se prolonga y sobrevive en tanto el inmigrante, ese doble inmigrante, no haya desaparecido o no ha sido olvidado como tal. [...] A medida que los contactos de los inmigrantes con la sociedad receptora se prolongan y se intensifican, a medida que gana nuevos espacios, el inmigrante sale de la esfera en la cual su estatuto y su condición le están asignados. (Sayad, 2006, p.15, traducción del francés: Régis Minvielle)

\section{Conclusión: Identidades en movimiento}

En conclusión, la llegada de los africanos a Buenos Aires no se realizó de manera discreta. Apropiándose del espacio público, generan primero la curiosidad de los porteños poco acostumbrados a ver africanos fuera del flujo de imágenes televisivas. En la pantalla, el 'africano', entidad única, es a menudo interiorizado y a veces exotizado. Quedándose horas en la calle a la búsqueda de clientes, los vendedores ambulantes son los más expuestos a los prejuicios y lugares comunes. Mientras ellos reaccionan con indignación frente a los estereotipos, los pioneros, sobre todo los que conocen trayectorias más ascendentes, adoptan un discurso más matizado subrayando que el racismo se expresa de manera universal. 
A pesar de los prejuicios, las "identidades étnicas no son ni monolíticas, ni exclusivas" (Mazzella, 2001). Estas conclusiones procedentes de las observaciones de la autora sobre las migraciones en Marsella, Francia, se verifican también en Buenos Aires. Las experiencias y los lazos que los africanos desarrollan con otros grupos sociales y culturales participan de una redefinición de las fronteras identitarias y étnicas basadas ahora en la fluidez y la flexibilidad. Por fuera de las relaciones íntimas, los africanos construyen también lazos y solidaridades, comparten el espacio público con otras comunidades migrantes. Aunque la comunidad de origen constituye un recurso para los migrantes, también están en capacidad de explotar los recursos de sus nuevos espacios de vida. Por ejemplo, construyeron relaciones de negocio con otros comerciantes migrantes, como los sur-coreanos, a quienes compran la bisutería. Negocian también con otros vendedores ambulantes peruanos o paraguayos para instalar una mesa en el espacio público. Estas conexiones cosmopolitas impulsadas por las varias comunidades de migrantes participan así de la construcción de una sociedad multicultural en reconfiguración permanente.

\section{Referencias}

Alberdi, J.B. (1852). Bases y puntos de partida para la organización de la República Argentina. Buenos Aires: Centro Editor de América Latina.

Amselle, J. L. (2001). Branchements: anthropologie de l'universalité des cultures. Paris: Flammarion.

Briones, C., Cañuqueo, L., Kropff, L. y Leuman, M. (2007). Escenas del multiculturalismo neoliberal. Una proyección desde el Sur. Buenos Aires: CLACSO, Consejo Latinoamericano de Ciencias Sociales.

Contarino Sparta, L. (1998). La comunidad caboverdiana en La Provincia de Buenos Aires: Una historia ligada a la navegación. Revista de Historia Bonaerense, IV(16), 49-51. 
Devoto, F.(2009).Historia de la Inmigración en la Argentina. Buenos Aires: Editorial Sudamericana.

Diop, A. B. (1985). La famille wolof. Paris: Karthala.

Frigerio, A. (2005). Migrantes exóticos: Los Brasileros en Buenos Aires. Runa, (XXV), 97-121.

Frigerio, A. (2008). De la "desaparición" de los negros a la "reaparición" de los afrodescendientes: Comprendiendo la politica de las identidades negras, las clasificaciones raciales y de su estudio en la Argentina. En Lechini, G. Los estudios afroamericanos y africanos en América Latina: herencia, presencia y visiones del otro (pp. 117-144.). Buenos Aires: Centro de Estudios Avanzados, Programa de Estudios Africanos, Córdoba; Clacso, Consejo Latinoamericano de Ciencias Sociales.

Goffman,E., (1963). Estigma. La identidad deteriorada. Buenos Aires: Ed. Amorrortu.

Guillaumin, C. (2002 / 1972). L’idéologie raciste: genèse et langageactuel. Paris: Gallimard.

Kleidermacher, G. (2011). Africanos y afrodescendientes en la Argentina: invisibilización, discriminación y racismo. Revue Rita, (5). Disponible en: http:/ / www.revue-rita.com/traits-dunion98/africanos-y-afrodescendientes-en-laargentina-invisibilizacion-discriminacion-y-racismo.html.

Maffia, M. y Ceirano, V. (2007, agosto). Estrategias politicas y de reconocimiento en lacomunidad caboverdiana de Argentina. Contra Relatos desde el Sur. Apuntes sobre África y Medio Oriente, III(4), 81-107

Maffia, M. P., Zubrzycki, B., Agnelli, S. y Ottenheimer, A. C. (2012). Dinámicas asociativas entre los inmigrantes africanos subsaharianos en la Argentina. En Mbuyi Kabunda Badi (Coord.). África en movimiento. Migraciones hacia Latinoamérica. Madrid: Observatorio sobre la Realidad Social del África Subsahariana (FCA-UAM). 
Mazzella, S. (2001). L'arrière-boutique du port de Marseille: commerçantsétablis et kamikazes d'originemaghrébine. En M. Peraldi, Cabas y Containers. Activités marchandes informelles et réseaux migrants transfrontaliers (pp. 133-164.). Paris:Maisonneuve et Larose.

Nal, E. (2012). L'étranger - l'être, la figure, le symbole : un messager du sens?Le Télémaque, 1(41), 103-113.

Palidda, S. (1999). La criminalisation des migrants.Actes de la Recherche en Sciences Sociales, CXXIX1(1), 39-49.

Pezeril,C. (2007). Réflexivité et dualitésexuelle.Journal des anthropologues, 108-109, 353-380.

Poiret,C. (2011). Les processusd'ethnicisation et de raci(ali)sationdans la France contemporaine: Africains, Ultramarins et "Noirs".Revueeuropéenne des migrationsinternationales, XXVII(1), 107-127.

Sayad, A. (2006). L’immigrationou les paradoxes de l'altérité. 1. L'illusion du provisoire. Paris: Raisonsd'agir.

Schnapper, D. 1986). Modernité et acculturations. Communications, (43), 141-168.

\section{Cómo citar este artículo}

Minvielle, R. (2015). Migrantes africanos en Buenos Aires: Entre estigmatización y exotización. Universitas Humanística, 80, 79-105. http:/ /dx.doi.org/10.11144/ Javeriana.UH80.maba 